\title{
A witch defended by a psychiatrist
}

\author{
Manohar Dhadphale
}

Professor and Academic Head, Kamala Nehru Hospita Pune, India, email Manohar dhadphale@yahoo.co.uk
Some 40 years ago I was at a loss when I was summoned as an expert witness in an indigenous tribal court to defend a witness accused of witchcraft. The experience shows how the psychiatrist's work requires knowledge of an individual's spiritual framework.

Ideas of the supernatural are ubiquitous. However, few Western-educated psychiatrists are trained to write a court report on cases of spirit possession and the like. Psychiatrists operating in a different culture are expected to study the local traditional belief system. They ought to understand the local credo and familiarise themselves with mental illness presenting in the guise of black magic or spirit possession.

Some 40 years ago I was initially at a loss when I was summoned as an expert witness in an indigenous tribal court in Zambia. The prosecutor asked me many challenging and at times unnerving questions. The experience shows how the psychiatrist's work requires knowledge of an individual's spiritual framework.

\section{The case}

In a commanding voice, the senior judge in the tribal court asked me: 'What do you know about witchcraft, doctor? Can you please tell this court about your experience in dealing with cases of witchcraft?' The judge was a towering figure in his early 50s; he had the reputation of being well versed in tribal customs, philosophy and history. I had been summoned as an expert witness, to present my report in a police case involving a 'witch'. A 56-year-old woman, Maria, was accused of having kidnapped a 14-year-old girl, Anne, using witchcraft. The court had two witness boxes. I stood in one while the other was occupied by the accused 'witch'. The family of the aggrieved girl sat among the spectators. Many from Maria's township had crowded the court and the press was also present to report on this sensational case.

With some trepidation I told the judge politely: 'I have lived in rural Africa for many years and am familiar with the traditional concepts colloquially known as witchcraft.' The court appeared satisfied with this. A little emboldened I revealed to the court my recently published scientific paper in the East African Medical Journal on ngulu (Dhadphale, 1979). (The term ngulu is a general one that includes spirit possession, witchcraft, sorcery, bewitchment and some cultural concepts of supernatural phenomena.) I also quoted a few African references from the paper and brought to the notice of the court my 15 years' experience in rural Africa. My paper had investigated traditional beliefs about witchcraft among 16- to 18-year-old Zambian girls. I had asked (among other things) whether they believed that ngulu does exist and affects individuals. The response was highly significant: all respondents believed that witchcraft does exist and is not imagined. Further, they agreed that Western medical practitioners do not understand witchcraft and should refer all ngulu victims to traditional healers. Only the latter understand and are able to treat spirit possession. Regarding the relationship between mental illness and ngulu, most of them believed they were linked.

The prosecutor then started a barrage of queries. I had some difficulty in answering to his satisfaction. He wanted me to say either yes or no. I told the court that it was not so simple. He was trying to prove to the court that Maria was guilty and to convict her of the serious crime of child abduction. The crowd and the prosecutor did not like what I said in defence of Maria: that she was not guilty by reason of mental illness. I asked that the prosecutor be advised to deal with the evidence before the court with sensitivity and to put his personal views aside.

Three months earlier, the local papers had sensationalised the original incident. An angry crowd had gathered outside Maria's house, threatening to burn it down. People alleged that Maria, a known witch, had kidnapped a girl from the neighbourhood and hidden her. The police were called as people had become rowdy and potentially violent. They ordered the crowd to disperse peacefully but the mob was becoming unmanageable.

After dispersing the crowd with tear gas, the police started their investigation by searching Maria's cottage but they could not find the missing girl. Over the years, Maria had earned a dubious reputation as a wicked witch possessing the supernatural power to make people vanish. Local people claimed that she particularly enjoyed abducting small girls. The police arrested Maria and charged her with child abduction. At the preliminary enquiry by the local magistrate, her defence lawyer claimed that Maria was insane. A psychiatric report was required before she could be charged with the serious offence of child abduction (which would have attracted a long prison sentence). Maria was sent to my unit for a psychiatric assessment. I was ordered to report whether she was insane or a witch.

She was admitted and put on close observation. I ordered day and night reports, with a close watch on her behaviour, especially her interaction with the staff and visitors, and particularly with children. Our social worker visited her home and talked to the family of the victim and neighbours. 
After 7 weeks of observation, a ward case conference was held, attended by my whole team. Conclusions were drawn and I submitted my report to the court and awaited further instruction. The report stated that Maria had chronic schizophrenia and was currently in a defect state. She had relapsed in the past, with frank delusions of being a witch and hearing God's voice tell her that she had extraordinary powers to make anyone disappear. She was of somewhat low intelligence. She had no children of her own and liked playing with small children from the neighbourhood. She longed for a daughter of her own and sometimes claimed someone else's child and was unwilling to return the child to the parents. No one took her seriously. During psychotic relapse she boasted of her supernatural prowess. It was during such a relapse that the recent incident had occurred.

Thus, Maria was mentally ill and needed psychiatric care. By reason of her mental condition, she was not responsible for the offence. I asked the court to issue an order for Maria's treatment.

The prosecutor tried to demolish my report by quoting cases of witchcraft he had seen. He told the court to reject my report in toto, as no one in the local population believed that Maria was mad or mentally ill: she was a witch and used witchcraft to kidnap children. He wanted the court to convict her as charged and asked that Maria be given exemplary punishment in order to deter other acts of child abduction. He wondered whether a Westerntrained psychiatrist knew anything at all about indigenous illnesses or was aware of ngulu.

The court rejected the prosecution's arguments and accepted my report. Maria was remanded to a mental ward. Most members of the public were not entirely satisfied with the verdict and left the court in disappointment. Maria was duly admitted to my ward, was treated with depot injections and was asymptomatic 3 years later.

\section{Comment}

Maria fitted the traditional stereotype of a witch. Her local community did not believe that she had a mental disorder, even after the court verdict. They also doubted my knowledge and understanding of indigenous illness. Laher (2014), in her study of illness conceptualisation in African, Hindu and Islamic faiths, recommends that the training of mental health workers include knowledge of local culture, skills and awareness. I have held this view and have incorporated it in my teaching.

The fall-out of this case was interesting. The press debated witchcraft vis-à-vis mental illness and argued whether traditional healers and Western-trained mental health workers could work together. I followed their suggestion and sought the advice of known healers to assist me in managing some cases of ngulu. From his personal experience in Nigeria, Prince (1964) has suggested that traditional healers have a role in dealing with cases of spirit possession and could be helpful in treatment. Cooperation between Western-trained psychiatrists and traditional healers was rewarding. Some years later I learned with regret that the arrangement with healers had been discontinued.

In the early 1980s, while doing research in primary health clinics in rural Kenya, I found that a significant number of patients with a diagnosable mental illness seen in psychiatric clinics (urban as well as rural) had visited traditional healers. Therefore, Western-trained psychiatrists should familiarise themselves with the local concepts of mental illness and spirit possession. This idea is well supported by Incayawar et al (2009); they term this an 'unwitting partnership'. I have been unable to find any reference to a psychiatrist having defended a psychotic witch in a traditional court.

\section{References}

Dhadphale, M. (1979) Attitude of a group of Zambian females to spirit possession. East African Medical Journal, 56, 450-453.

Incayawar, M., Wintrob, R. \& Bartocci, G. (eds) (2009) Psychiatrists and Traditional Healers - Unwitting Partners in Global Mental Health. Wiley.

Laher S. (2014) An overview of illness conceptualizations in African, Hindu and Islamic traditions: towards cultural competence. South African Journal of Psychology, 44, 191-204.

Prince, R. (1964) Indigenous Yoruba psychiatry. In Magic, Faith and Healing (ed. A. Kiev), pp. 84-120. Free Press.

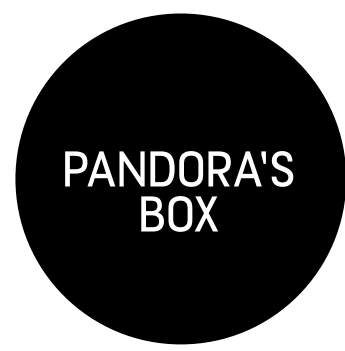

Pandora searches the world literature for evidence, news and other sources on matters of interest (doesn't shy away from controversy) to bring to the from controversy) to bring to the ander. She welcomes comments and suggestions (via ip@rcpsych. ac.uk)

\section{MDGs a missed opportunity?}

Tack of investment in mental health is a key $\mathcal{U}$ driver of poverty and inequality in low- and middle-income countries. Neuropsychiatric disorders account for $13 \%$ of the global burden of disease, with $70 \%$ of these accounted for by lowand middle-income countries. The year 2000, a time of optimism, marked the Millennium Declaration, and the start of the Millennium Development Goals (MDGs), a 15-year international agenda for global development, was greeted with hope. That programme focused on health challenges, guiding health budgets of national governments, non-governmental organisations (NGOs) and the wider aid community, and its achievements should not be underestimated. However, it was a missed opportunity as far as mental health is concerned. According to McGovern, in a commentary appearing in the International Journal of Mental Health Systems, the MDGs failed adequately to consider mental health and he urges that a specific focus be placed on mental disorders in the post-2015 agenda for development. He argues that investment in mental health pays wider dividends than purely on the level of clinical outcomes, and recommends that the post-2015 agenda specifically includes access to mental healthcare and the use of evidence-based diagnosis and management. Better investment in mental health can address the global burden of mental disorders.

McGovern, P. (2014) Why should mental health have a place in the post-2015 global health agenda? International Journal of Mental Health Systems, 8, 38 